\title{
Faktor-Faktor yang Mempengaruhi Niat Penggunaan Sistem Informasi Terkomputerisasi pada UKM (Pendekatan Theory of Planned Behavior)
}

\author{
Kurnia Rizki Amanda \\ Fakultas Ekonomika dan Bisnis Jurusan Akuntansi-Universitas Kristen Satya Wacana

\section{Mitha Dwi Restuti} \\ Fakultas Ekonomika dan Bisnis Jurusan Akuntansi-Universitas Kristen Satya Wacana \\ mitha.restuti@staff.uksw.edu
}

\begin{abstract}
The information system is a set of related components which serves to collect, process store, and distribute information either done manually or with the aid of a computer to generate information that is useful in decision making. This study aims to examine the factors that affect interest in the use of computerized information systems by perpetrators of Small and Medium Enterprises (SMEs) for decision making by using three variables of the Theory of Planned Behaviour proposed by Ajzen (1991) which are attitude, subjective norms, and perceived behavior control. Fifty-two SMEs in Salatiga have been surveyed and used as a sample. Results from multiple regression analysis showed that perceived behavior control variables affect the interest of the use of computerized information systems. The results showed that the SMEs believe that the use of computerized information systems is easy to do so that SMEs are interested in using the computerized information systems. While the attitude and subjective norm does not affect the interest in the use of computerized information systems, which means that the SMEs have the notion that using computerized SI is not important and the perception of the people around did not affect the interest of SMEs to use the computerized information system.
\end{abstract}

Keywords: Interest in the use of computerized information systems; Small and Medium Enterprises (SME); Theory of Planned Behaviour

\section{Pendahuluan}

Usaha Kecil Menengah (UKM) merupakan salah satu sektor strategis dalam perekonomian nasional. Hal ini tercermin dari besarnya penyerapan tenaga kerja oleh sektor UKM. Berdasarkan data Kementerian Koperasi dan UKM menyebutkan bahwa 
pada tahun 2013 jumlah tenaga kerja di sektor UKM sebesar 9,5 juta pekerja. Adapun jumlah UKM sebanyak 706 ribu unit. Sektor UKM memiliki peran penting dalam mendorong pertumbuhan perekonomian Indonesia. Dengan adanya sektor UKM, pengangguran akibat angkatan kerja yang tidak terserap dalam dunia kerja menjadi berkurang. Sektor UKM pun telah terbukti menjadi pilar perekonomian yang tangguh saat terjadi krisis ekonomi tahun 1998. Meskipun demikian, UKM sangat berat dalam menghadapi persaingan dengan perusahaan-perusahaan besar dan lebih modern. Kemampuan bersaing di pasar sangat menentukan kelangsungan hidup suatu perusahaan, demikian pula dengan UKM. Di Indonesia sebagian UKM menjalankan usahanya dengan cara-cara tradisional, padahal saat ini perusahaan bersaing melalui kecanggihan teknologi dan IT untuk bisa memenangkan persaingan.

Sistem Informasi Akuntansi (SIA) dapat digunakan sebagai penyedia informasi yang ditujukan untuk pengguna laporan keuangan dalam rangka pengambilan keputusan. SIA menghasilkan informasi keuangan yang bisa dipercaya, relevan, tepat waktu, dapat dipahami dan teruji kebenarannya untuk membantu dalam proses pengambilan keputusan ekonomis (Rosita 2013). Sistem akuntansi berbasis komputerisasi dapat membantu UKM untuk meningkatkan usaha dan mengatasi masalah yang ada di UKM (DeLone 1988).UKM sangat berkepentingan terhadap penggunaan sistem informasi berbasis komputer agar bisa berdaya saing dengan entitas yang lebih besar, namun masih banyak UKM yang belum menggunakan sistem informasi (SI) terkomputerisasi dalam usahanya. Penelitian ini menganalisis faktor yang mempengaruhi niat penggunaan sistem informasi terkomputerisasi pada UKM menggunakan pendekatan Theory of Planned Behavior. Objek penelitian ini adalah UKM di Salatiga, karena Salatiga merupakan daerah penyangga dari sebagian wilayah Kabupaten Semarang dan berada pada jalur perdagangan dan transportasi kawasan Joglosemar (Jogyakarta, Solo dan Semarang) yang sangat padat arus mobilitas lalu lintas darat.

\section{Kerangka Pemikiran dan Hipotesis}

\section{Pengaruh Sikap terhadap Niat Penggunaan Sistem Informasi Terkomputerisasi}

Sikap adalah tingkat dimana individu memiliki evaluasi yang positif atau negatif terhadap suatu perilaku tertentu (Ajzen 1991). Ketika pelaku UKM beranggapan bahwa penggunaan SI terkomputerisasi tidak penting karena usaha yang dijalankan merupakan usaha keluarga dan tidak begitu besar maka terbentuk sikap yang membuat pelaku UKM tidak berniat menggunakanSI terkomputerisasi.Sebaliknya, jika pelaku UKM beranggapan bahwa penggunaan SI terkomputerisasi tidak hanya diterapkan oleh korporasi besar tetapi seharusnya juga diterapkan oleh UKM dalam rangka mengembangkan usahanya, maka akan terbentuk sikap positif, selain itu jika pelaku UKM beranggapan bahwa SI terkomputerisasi dapat memberikan keuntungan untuk mengontrol usahanya seperti mengetahui posisi keuangan usahanya, memperoleh informasi akuntansi dengan lebih mudah, juga mengurangi human error maka akan terbentuk sikap positif dari pelaku UKM sehingga pelaku UKM akan berniat untuk menggunakan SI terkomputerisasi. Penelitian sebelumnya yang dilakukan oleh Filadelfia (2015), menyatakan bahwa niat pelaku UMKM atas pengadaan pembukuan dipengaruhi oleh variabel sikap (attitude).

H1 : Sikap (attitude) berpengaruh terhadap niat (intention) atas penggunaan sistem informasi terkomputerisasi. 


\section{Pengaruh Norma Subjektif terhadap Niat Penggunaan Sistem Informasi Terkomputerisasi}

Norma subjektif adalah pertimbangan seseorang sehubungan dengan apakah orang lain beranggapan bahwa dia perlu melakukan hal tersebut atau tidak (Ajzen 1991). Norma subjektif pelaku UKM atas penggunaan SI terkomputerisasi terbentuk dari lingkungan sekitar juga dengan usaha yang sejenis. Ketika UKM lain di lingkungan sekitar ataupun UKM lain pada usaha yang sejenis tidak menggunakan SI terkomputerisasi dan usahanya masih bisa berjalan, maka terbentuk norma subjektif yang membuat pelaku UKM tidak berniat menggunakan SI terkomputerisasi. Sebaliknya, apabila orang disekitar misalnya teman atau keluarga merekomendasikan untuk menggunakan SI terkomputerisasi, serta UKM lain di lingkungan sekitar ataupun UKM lain pada usaha yang sejenis menggunakan SI terkomputerisasi dan usahanya berjalan dengan baik dan lebih maju, maka terbentuk norma subjektif yang membuat pelaku UKM berniat untuk menggunakan SI terkomputerisasi. Penelitian sebelumnya yang dilakukan oleh Grafiti (2014) menyatakan bahwa niat pelaku UMKM untuk menyusun laporan keuangan dipengaruhi oleh variabel norma subjektif (subjective norm).

$\mathrm{H} 2$ : Norma subjektif (subjective norm) berpengaruh terhadap niat (intention) atas penggunaan sistem informasi terkomputerisasi.

\section{Pengaruh Kontrol Perilaku Persepsian terhadap Niat Penggunaan Sistem Informasi Terkomputerisasi}

Kontrol perilaku persepsian adalah suatu kondisi dimana individu percaya bahwa suatu tindakan itu mudah atau sulit dilakukan di bawah kontrol individu (Ajzen 1991). Ketika UKM mengalami kesulitan dalam menggunakan SI terkomputerisasi karena merupakan pekerjaan yang teknikal juga biaya pemasangan sistem yang akan menjadi beban (biaya) bagi pelaku UKM, maka terbentuk kontrol perilaku persepsian yang membuat pelaku UKM tidak berniat menggunakan SI terkomputerisasi. Sebaliknya, jika pelaku UKM beranggapan bahwa penggunaan SI terkomputerisasi akan dapat mengurangi upaya (tenaga dan waktu) dalam melakukan pekerjaan, juga pekerjaan dapat dilakukan secara lebih cepat maka akan terbentuk sikap positif. Selain itu, apabila pelaku UKM memiliki ketersediaan danayang memadai untuk membayar proses pemasangan sistem maka akan mempermudah UKM dalam penggunaan sistem informasi terkomputerisasi. Dengan kondisi seperti itu, pelaku UKM memiliki kontrol perilaku persepsian yang beranggapan bahwa penggunaan SI terkomputerisasi mudah untuk dilakukan sehingga pelaku UKM berniat menggunakan SI terkomputerisasi. Penelitian sebelumnya yang dilakukan oleh Saputra (2014) menyatakan bahwa niat penerapan e-commerce untuk usaha mikro dipengaruhi oleh kontrol perilaku persepsian (perceived behavior control). H3 : Kontrol perilaku persepsian (perceived behavior control) berpengaruh terhadap niat (intention) atas penggunaan sistem informasi terkomputerisasi.

\section{Kerangka Teoritis}

\section{Sistem Informasi Terkomputerisasi}

Menurut Sutedjo (2002), sistem adalah kumpulan elemen yang saling berhubungan satu sama lain yang membentuk satu kesatuan dalam usaha mencapai suatu tujuan. Informasi merupakan hasil pengolahan data sehingga menjadi bentuk yang penting bagi penerimanya dan mempunyai kegunaan sebagai dasar dalam pengambilan keputusan 
yang dapat dirasakan akibatnya secara langsung saat itu juga atau secara tidak langsung pada saat mendatang (Sutanta2003).

Menurut Mulyono (2009), sistem informasi merupakan seperangkat komponen yang saling berhubungan yang berfungsi mengumpulkan, memproses, menyimpan, dan mendistribusikan informasi untuk mendukung pembuatan keputusan dan pengawasan dalam organisasi. Sistem informasi adalah suatu tipe khusus dari sistem kerja yang fungsi internalnya terbatas pada pemrosesan informasi dengan melakukan enam tipe operasi: menangkap (capturing), mentransmisikan (transmitting), menyimpan (storing), mengambil (retrieving), memanipulasi (manipulating), dan menampilkan (displaying) informasi (Jogiyanto 2007).

Sistem informasi merupakan suatu sistem yang berkaitan dengan pengumpulan, penyimpanan, dan pemrosesan data, baik yang dilakukan secara manual maupun dengan bantuan komputer untuk menghasilkan informasi yang berguna dalam pengambilan keputusan. Stair (1992) dalam Al Fatta (2007) menjelaskan bahwa sistem informasi berbasis komputer dari suatu organisasi terdiri dari komponen-komponen, yaitu perangkat keras, perangkat lunak, database, telekomunikasi, dan manusia.

\section{Theory of Planned Behavior}

Theory of Planned Behavior (TPB) merupakan perkembangan lebih lanjut dari Theory of Reasoned Action (TRA). Kelebihan dari Theory of Planned Behavior yaitu dalam menganalisis suatu situasi di saat individu-individu tidak memiliki kontrol sendiri terhadap sumber-sumber daya yang mereka perlukan, pengetahuan, dan kesempatan yang mereka peroleh (Grafiti 2014). Teori ini dikembangkan oleh Ajzen (1991) dengan menambahkan sebuah konstruk yaitu kontrol perilaku persepsian (perceived behavioral control) yang dipersepsikan akan mempengaruhi niat dan perilaku. Konstruk ini ditambahkan di TPB untuk mengontrol perilaku individual yang dibatasi oleh sekurangkurangnya dan keterbatasan-keterbatasan dari kekurangan sumber daya yang digunakan untuk melakukan perilaku (Chau dan $\mathrm{Hu} 2001$ ).

Theory of Planned Behavior adalah teori yang meramalkan pertimbangan perilaku karena perilaku dapat dipertimbangkan dan direncanakan (Filadelfia 2015).Peachetal., (2006); Wellington etal,. (2006) dalam Nuary (2010), menyatakan bahwa Theory of Planned Behavior memiliki keunggulan dibandingkan teori keperilakuan yang lain, karena Theory of Planned Behavior merupakan teori perilaku yang dapat mengidentifikasikan keyakinan seseorang terhadap pengendalian atas sesuatu yang akan terjadi dari hasil perilaku, sehingga membedakan antara perilaku seseorang yang berkehendak dan yang tidak berkehendak.

Model Theory of Planned Behavior menjelaskan bahwa niat berperilaku seseorang yang dipengaruhi oleh tiga faktor. Faktor-faktor tersebut antara lain sikap, norma subjektif, dan kontrol perilaku persepsian.Sikap terhadap suatu perilaku (attitude toward behavior) mengacu pada tingkat seseorang mengevaluasi suatu perilaku itu baik atau tidak baik, dan dapat pula dikatakan penelitian seseorang terhadap suatu perilaku. Sikap terhadap suatu perilaku (attitude toward behavior) ditentukan oleh keyakinan terhadap suatu perilaku (behavior beliefs) dan biaya atau keuntungan dari perilaku tersebut (Ajzen 1991). Sikap yang dimaksud termasuk perasaan tentang sesuatu yang ingin dicapai dari perilaku yang dia lakukan (Sharma etal., 2003).

Norma subjektif (subjective norm) adalah persepsi atau pandangan seseorang terhadap kepercayaan-kepercayaan orang lain yang akan mempengaruhi niat untuk melakukan atau tidak melakukan suatu perilaku (Fishbein dan Ajzen 1975). Normanorma subjektif secara definisi merupakan pengaruh "orang lain yang penting". Hal ini 
biasanya dipersepsikan sebagai sesuatu yang dipikirkan "orang lain yang penting" (important person) yang harus dilakukan oleh orang-orang tersebut dengan perilaku tertentu (Engel etal., 1994 dalam Filadelfia 2015). Dharmmesta (1999) menyatakan bahwa norma subjektif adalah tekanan sosial yang dirasakan seseorang untuk melakukan atau tidak melakukan tindakan atau perilaku.

Perceived behavioral control yaitu keyakinan individu mengenai ada atau tidak faktor pendukung atau penghambat untuk melakukaan suatu perilaku (Ajzen 2004). Kontrol perilaku persepsian merupakan kondisi pada saat orang percaya bahwa suatu tindakan itu mudah atau sulit dilakukan (Dharmmesta 1999). Grizzell (2003) dalam Magfiroh (2015) menyebutkan bahwa perceived behavioral control hampir sama dengan konsep self efficiency, yaitu persepsi orang untuk kemampuannya pada saat melakukan tindakan atau perilaku.

\section{Metode Penelitian}

\section{Sampel dan Metode Pengumpulan Data}

Sampel dalam penelitian ini adalah pelaku UKM di Kota Salatiga yang berjumlah 52 UKM. UKM di Kota Salatiga dipilih karena berada pada jalur perdagangan dan transportasi dikawasan Joglosemar (Jogyakarta, Solo dan Semarang) yang cukup padat arus mobilitas lalu lintas darat.

Metode pengumpulan data yang digunakan dalam penelitian ini adalah metode survei dengan cara menyebarkan kuesioner ke pelaku UKM yang berlokasi di Kota Salatiga.

\section{Definisi Operasional dan Pengukuran Variabel}

Variabel yang terdapat pada penelitian ini adalah variabel terikat (dependen) dan variabel bebas (independen). Variabel terikat atau dependen pada penelitian ini adalah niat (intention) atas penggunaan SI terkomputerisasi. Selain itu, sikap (attitude), norma subjektif (subjective norm), kontrol perilaku persepsian (perceived behavior control) adalah variabel bebas atau independen.

Tabel 1

Variabel Operasional

\begin{tabular}{l} 
Definisi \\
\hline$\underline{\text { Attitude }}$ \\
Evaluasi kepercayaan \\
(belief) atau perasaan positif \\
atau negatif dari seseorang \\
jika harus melakukan \\
perilaku yang akan \\
ditentukan. \\
( Ajzen, 1991)
\end{tabular}

1. Penggunaan SI terkomputerisasi memiliki peran penting untuk memperoleh informasi mengenai posisi keuangan usaha.

2. Penggunaan SI terkomputerisasi dapat membantu pengembangan usaha.
Grafiti (2014) dengan modifikasi
3. SI terkomputerisasi merupakan salah satu alat yang digunakan manajemen untuk menghadapi persaingan usaha.

\section{Sumber}




\section{$\underline{\text { Subjektive Norm }}$}

Persepsi atau pandangan seseorang terhadap kepercayaan-kepercayaan orang lain yang akan mempengaruhi niat untuk melakukan atau tidak melakukan perilaku yang sedang dipertimbangkan. ( Ajzen, 1991)

\section{Perceived Behavior Control}

Kemudahan atau kesulitan persepsian untuk melakukan perilaku. (Ajzen, 1991)

\section{$\underline{\text { Niat }}$}

Niat yang dimiliki

oleh seseorang untuk

cenderung mengadopsi

suatu perilaku (Ajzen,1991)
4. Menggunakan SI terkomputerisasi bukanlah pekerjaan yang membuang buang waktu.

1. Di lingkungan sekitar, UKM lain pada bidang usaha sejenis sudah banyak menggunakan SI terkomputerisasi.

2. Usaha lain yang menggunakan SI terkomputerisasi usahanya lebih maju.

3. Orang-orang di sekitar menyarankan untuk menggunakan SI terkomputerisasi.

Filadelfia(2014) dengan modifikasi

Saputra (2014) dengan modifikasi

Grafiti (2014) dengan modifikasi membantu menggunakan SI terkomputerisasi.

3. Tidak akan kesulitan dalam menggunakan SI terkomputerisasi.

4. Tidak akan kesulitan dalam memahami SI terkomputerisasi.

1. Berniat untuk menggunakan SI terkomputerisasi.

2. Saya bermaksud mengerjakan sendiri atau dengan jasa orang lain untuk menggunakan SI terkomputerisasi.

Filadelfia (2014) dengan modifikasi

\section{Pengujian Hipotesis}

Pengujian hipotesis dilakukan menggunakan analisis regresi berganda. Persamaan regresi adalah sebagai berikut:

Keterangan :

$$
\mathrm{Y}=\mathrm{a}_{0}+\mathrm{a}_{1} \mathrm{X}_{1}+\mathrm{a}_{2} \mathrm{X}_{2}+\mathrm{a}_{3} \mathrm{X}_{3}+\mathrm{e}
$$

$\mathrm{Y}$
$\mathrm{X}_{1}$
$\mathrm{X}_{2}$
$\mathrm{X}_{3}$
$\mathrm{a}_{0}$
$\mathrm{a}_{0 . .} \mathrm{a}_{3}$
$\mathrm{e}$

= Niat menggunakan SI terkomputerisasi

$=$ Sikap

$=$ Norma Subyektif

= Kontrol Perilaku Persepsian

$=$ konstanta (intersep)

= koefisien regresi dari X1... X3

$=$ kesalahan pengganggu (error) 


\section{Hasil Penelitian dan Pembahasan}

\section{Gambaran Umum Responden}

Responden dalam penelitian ini berjumlah 52 responden yang telah diperoleh dari distribusi kuesioner dengan pemilik UKM di Kota Salatiga.Penelitian dilakukan pada bulan Oktober dan November 2016. Gambaran umum responden dapat dilihat dalam tabel 2. Karakteristik usaha dapat dilihat pada tabel 3.

Tabel 2

Karakteristik Pelaku Usaha

\begin{tabular}{ccc}
\hline & $\begin{array}{c}\text { Jumlah } \\
\text { Responden }\end{array}$ & Presentase \\
\hline A. Usia (Tahun) & 8 & $15 \%$ \\
$21-30$ & 12 & $23 \%$ \\
$31-40$ & 18 & $35 \%$ \\
$41-50$ & 14 & $27 \%$ \\
$>$ 50 & $\mathbf{5 2}$ & $\mathbf{1 0 0 \%}$ \\
\hline Jumlah & & \\
\hline B. Jenis Kelamin & 32 & $62 \%$ \\
Laki-laki & 20 & $38 \%$ \\
\hline Perempuan & $\mathbf{5 2}$ & $\mathbf{1 0 0 \%}$ \\
\hline C. Pendidikan Terakhir & & \\
\hline SD & 1 & $2 \%$ \\
SMP & 2 & $4 \%$ \\
SMA & 23 & $44 \%$ \\
D3 & 5 & $10 \%$ \\
S1 & 21 & $40 \%$ \\
\hline Jumlah & $\mathbf{5 2}$ & $\mathbf{1 0 0 \%}$ \\
\hline
\end{tabular}

Sumber: Olahan penulis 
Tabel 3

Deskriptif Karakteristik Usaha

\begin{tabular}{|c|c|c|}
\hline & $\begin{array}{c}\text { Jumlah } \\
\text { Responden }\end{array}$ & $\begin{array}{c}\text { Presentase } \\
(\%)\end{array}$ \\
\hline \multicolumn{3}{|l|}{ Usia Usaha (Tahun) } \\
\hline $0-10$ & 22 & $42 \%$ \\
\hline $11-20$ & 14 & $27 \%$ \\
\hline $21-30$ & 6 & $12 \%$ \\
\hline$>30$ & 10 & $19 \%$ \\
\hline Jumlah & 52 & $100 \%$ \\
\hline \multicolumn{3}{|l|}{$\underline{\text { Jumlah Tenaga Kerja }}$} \\
\hline $1-5$ & 31 & $59 \%$ \\
\hline $6-10$ & 17 & $33 \%$ \\
\hline$>10$ & 4 & $8 \%$ \\
\hline Jumlah & 52 & $100 \%$ \\
\hline \multicolumn{3}{|c|}{ Omzet/Penjualan Per Bulan (Rupiah)* } \\
\hline $25.000 .000-50.000 .000$ & 31 & $64 \%$ \\
\hline $50.000 .001-75.000 .000$ & 7 & $14 \%$ \\
\hline $75.000 .001-100.000 .000$ & 3 & $6 \%$ \\
\hline$>100.000 .000$ & 8 & $16 \%$ \\
\hline Jumlah & 49 & $100 \%$ \\
\hline
\end{tabular}

Sumber: Data olahan penulis

* 3 responden tidak menyebutkan omzet/penjualan per bulan

Statistik deskriptif dapat dilihat pada tabel 4.

Tabel 4

Deskripsi Variabel

\begin{tabular}{rlcc}
\hline No & \multicolumn{1}{c}{ Variabel } & Rata-Rata & St Dev \\
\hline 1 & Sikap & 3,913 & 0,769 \\
2 & Norma Subjektif & 3,516 & 0,876 \\
3 & Kontrol Perilaku Persepsian & 3,740 & 0,856 \\
4 & Niat & 4,031 & 0,802 \\
\hline & Sumber: Data olahan penulis & &
\end{tabular}




\section{Pengujian Hipotesis}

Data dalam penelitian ini sudah lolos uji reliabilitas, validitas dan uji asumsi klasik. Hasil pengujian hipotesis dapat dilihat pada tabel 5.

\section{Tabel 5}

\section{Uji Hipotesis}

\begin{tabular}{lrrr}
\hline \multicolumn{1}{c}{ Variabel } & Koef. Standar & \multicolumn{1}{c}{ T } & Sig. \\
\hline (Constant) & & 2,884 & 0,006 \\
Sikap & 0,226 & 1,529 & 0,133 \\
Norma Subjektif & $-0,092$ & $-0,528$ & 0,600 \\
Kontrol Perilaku Persepsian & $-0,424$ & 2,269 & 0,028 \\
R Square & 0,270 & & \\
Adjusted R-Square & 0,224 & & \\
F & 5,916 & & \\
Sig & 0,002 & & \\
\hline
\end{tabular}

Sumber : Data olahan penulis

Hasil olahan data menunjukkan bahwa variabel yang nilai signifikansinya lebih kecil dari alpha 0,05 adalah kontrol perilaku persepsian yang berarti variabel tersebut berpengaruh terhadap niat penggunaan SI terkomputerisasi. Sedangkan, variabel sikap $(0,133)$ dan norma subjektif $(0,600)$ tidak berpengaruh terhadap niat SI terkomputerisasi.

\section{Pembahasan}

Hasil pengujian dapat diketahui bahwa variabel sikap tidak berpengaruh terhadap niat penggunaan SI terkomputerisasi dengan nilai signifikansi $0,133(>0,05)$ sehingga hipotesis pertama tidak didukung. Hal ini menunjukkan bahwa sikap pelaku UKM di Salatiga terhadap sistem informasi terkomputerisasi tidak mempengaruhi niat mereka untuk menggunakan sistem informasi terkomputerisasi. Pelaku UKM di Salatiga beranggapan bahwa penggunaan SI terkomputerisasi tidak penting dan membuangbuang waktu, karena usaha yang dijalankan merupakan usaha keluarga dan tidak begitu besar. Bisa jadi pelaku UKM tidak mau mencoba untuk menggunakan SI terkomputerisasi karena mereka beranggapan bahwa dibutuhkan banyak biaya untuk membeli komputer atau memasang sistem yang akan digunakan, sehingga meskipun seseorang merasa penting untuk menggunakan SI terkomputerisasi dalam usahanya namun ketika kondisi keuangan sedang lesu maka mereka akan lebih memilih untuk menahan penggunaan SI terkomputerisasi. Atau sebaliknya, meskipun seseorang tidak merasa penting dengan penggunaan SI terkomputerisasi namun adanya desakan untuk pemenuhan kebutuhan usahanya maka menyebabkan penggunaan SI terkomputerisasi tetap dilakukan dalam usahanya.

Hasil pengujian dapat diketahui bahwa variabel norma subjektif tidak berpengaruh terhadap niat penggunaan SI terkomputerisasi dengan nilai signifikansi $0,600(>0,05)$ sehingga hipotesis kedua tidak didukung. Hal ini menunjukkan bahwa para pelaku UKM di Salatiga tidak memperhatikan apakah usaha lain disekitarnya sudah menggunakan SI terkomputerisasi atau tidak karena tanpa menggunakan SI terkomputerisasi usahanya masih bisa berjalan. Tidak berpengaruhnya norma subyektif 
bisa jadi disebabkan karena pelaku UKM memiliki referensi dan pertimbangan masingmasing, misalnya usahanya cukup besar namun sederhana dan hanya menjual beberapa jenis barang, maka mereka memutuskan untuk tidak menggunakan SI terkomputerisasi meskipun dukungan dari UKM lain untuk menggunakan SI terkomputerisasi cukup tinggi.

Hasil pengujian dapat diketahui bahwa variabel kontrol perilaku persepsian berpengaruh terhadap niat penggunaan SI terkomputerisasi dengan nilai signifikansi $0,028(<0,05)$ sehingga hipotesis ketiga dalam penelitian ini didukung. Hal ini berarti bahwa pelaku UKM memiliki kontrol perilaku persepsian yang beranggapan bahwa penggunaan SI terkomputerisasi mudah untuk dilakukan sehingga pelaku UKM berniat menggunakan SI terkomputerisasi. Hal tersebut dapat ditunjukkan dengan adanya indikator dalam kuesioner yang menyatakan bahwa tidak akan kesulitan dalam memahami dan menggunakan SI terkomputerisasi. Responden juga menyatakan mampu menyewa tenaga ahli dan dapat mencari karyawan yang dapat membantu menggunakan SI terkomputerisasi. Dengan demikian, adanya kontrol perilaku persepsian yang baik tersebut pada akhirnya mempengaruhi niat pelaku UKM untuk menggunakan SI terkomputerisasi. Hasil penelitian ini mendukung penelitian Grafiti (2014) yang menyatakan bahwa kontrol perilaku mempunyai pengaruh yang signifikan terhadap niat pelaku UMKM dalam menyusun laporan keuangan dan penelitian Saputra (2014) yang menyatakan bahwa kontrol perilaku persepsian yang paling mendorong niat usaha mikro untuk mengadopsi e-commerce.

\section{Simpulan dan Saran}

Pendekatan Theory of Planned Behavior dalam melihat faktor-faktor yang mempengaruhi niat penggunaan SI terkomputerisasi menunjukkan bahwa hanya variabel kontrol perilaku persepsian (perceived behavior control) yang berpengaruh terhadap niat penggunaan SI terkomputerisasi. Hal ini dipicu oleh adanya persepsi para pelaku UKM bahwa menggunakan SI terkomputerisasi itu tidak sulit dan dapat mengurangi upaya (tenaga dan waktu) dalam melakukan pekerjaan, juga pekerjaan dapat dilakukan secara lebih cepat. Sedangkan variable sikap (atittude) dan norma subjektif (subjective norm) tidak berpengaruh terhadap niat (intention) atas penggunaan SI terkomputerisasi. Hal ini berarti bahwa pelaku UKM memiliki anggapan bahwa menggunakan SI terkomputerisasi tidak penting dan persepsi dari orang sekitar tidak mempengaruhi niat pelaku UKM untuk menggunakan SI terkomputerisasi.

Saran untuk penelitian mendatang adalah bisa menggunakan pendekatan yang berbeda untuk mengetahui niat pelaku UKM dalam menggunakan SI terkomputerisasi. Penelitian mendatang bisa juga mendeskripsikan faktor-faktor yang menyebabkan kurangnya niat pelaku UKM dalam menggunakan SI terkomputerisasi.

\section{Daftar Pustaka}

Ajzen, Icek, 1991, “The Theory of Planned Behavior”. Organizational Behavior and Human Decision Processe. Vol. 50.

Ajzen, Icek., Brown, C. dan Carvajal, F, 2004, "Explaining the Discrepancy Between Intentions and Actions: The Case of Hypothetical Bias in Contingent Valuation.'University of Massuchusetts. Amherst. 
Al Fatta, Hanif., 2007,Analisis dan Perancangan Sistem Informasi, Yogyakarta : ANDI. Chau, P.Y.K. dan Hu, P.J.-H., 2001, "Information Technology Acceptance by Individual Professionals: A Model Comparison Approach", Decision Sciences, Volume 32(4).

DeLone, William H., 1988,"Determinants of Success for Computer Usage in Small Business",MIS Quaterly 12 (1): 51.

Dharmmesta, Basu Swastha., Khasanah, Umi., 1999,“Theory of Planned Behavior: An Application to Transport Service Consumer",Gadjah Mada International Journal of Business, 1999, I (1).

Filadelfia, Anggita., 2015,Faktor-Faktor yang Mempengaruhi Minat Pelaku Usaha Mikro Kecil Menengah atas Pengadaan Pembukuan (Studi pada UMKM di Kota Salatiga), Skripsi Fakultas Ekonomika dan Bisnis Universitas Kristen Satya Wacana Salatiga, Tidak Dipublikasikan.

Fishbein, M dan Ajzen, I., 1975,Belief, Attitude, Intention, and Behavior. London: Addison Wesley Publishing Co.

Grafiti, Arrindi Silfiana., 2014,Minat Pelaku UMKM untuk Menyusun Laporan Keuangan: Aplikasi Theory of Planned Behavior (Studi pada UMKM di Wilayah Bandungan). Skripsi Fakultas Ekonomika dan Bisnis Universitas Kristen Satya Wacana, Tidak dipublikasikan.

Jogiyanto, H., 2007,Sistem Informasi Keperilakuan (Edisi Revisi Ed), Yogyakarta: Andi Offset.

Maghfiroh., 2015,Pengaruh Faktor Personal, Faktor Sosial, Faktor Informasi dan Sikap terhadap Niat (Intensi) Membeli Makanan Berlabel Halal LPPOM-MUI pada Mahasiswa Non Muslim di UNY,Program Studi Pendidikan Ekonomi Fakultas Ekonomi Universitas Negeri Yogyakarta.

Mulyono, Imam., 2008, Uji Empiris Model Kesuksesan Sistem Informasi Keuangan Daerah (Sikd) dalam Rangka Peningkatan Transparasi dan Akuntabilitas Keuangan Daerah,Prosiding Simposium Nasional Akuntansi XII. Pekanbaru.

Nuary, Ficky Dima., 2010,Implementasi Theory of Planned Behavior dalam Adopsi ECommerce oleh UKM (Studi pada UKM yang berada di Kota Surakarta Tahun 2009). Universitas Sebelas Maret Surakarta.

Rosita., 2013,“Analisis Faktor-Faktor yang Mempengaruhi Minat Penggunaan Sistem Informasi Akuntansi pada UKM (Studi Empiris pada UKM di Kabupaten Karanganyar)",Graduasi, Vol. 29 Edisi Maret 2013.

Saputra, Arjuna Eka., 2014,"Penerapan E-Commerce untuk Usaha Mikro (Studi Kasus pada PD. Sasmita)”. Skripsi Fakultas Ekonomika dan Bisnis Universitas Kristen Satya Wacana Salatiga, tidak dipublikasikan.

Sharma, Pramodita., J. Chrisman, James., H. Chua, Jess., 2003, “Succession Planning as Planned Behavior: Some Empirical Results”. Family Business Review. 2003; $16 ; 1$.

Sutanta E., 2003,Sistem Informasi Manajemen Edisi pertama, Yogyakarta: Graha Ilmu.

Sutedjo B., 2002, Perencanaan dan Pembangunan Sistem Informasi,Yogyakarta: Andi Offset. 